УДК: 372.161

DOI:

Світлана Яців, кандидат педагогічних наук, доиент кафедри англійської філології Прикарпатського начіонального університету імені Василя Стефаника

\title{
ФОРМУВАННЯ МОВЛЕННСВОЇ КУЛЬТУРИ СТУДЕНТІВ-ПЕРШОКУРСНИКІВ У РАКУРСІ ВИКЛИКІВ СЬОГОДЕННЯ
}

Порушено актуальну проблему - формування культури мовлення майбутнього фахівия, адже сьогодення ставить перед вищою школою завдання підготувати висококваліфікованих працівників, які досконало володіють професійним мовленням, послуговуються офіиійно-діловим, науковим та іншими стилями, мають чітке уявлення про терміни та доречне і правильне їх використання у професійному мовленні, уміють висловлюватися на професійну тему, володіють мовленнєвою культурою тощо. Рівень мовленнєвої культури студентів підвищиться, якщь: формування мовленнєвих умінь і навичок майбутніх фахівців здійснювати на комунікативно-діяльнісній основі; основну увагу на заняттях з украйнської мови (за професійним спрямуванням) приділяти розвитку усного мовлення студентів з урахуванням особливостей регіону, мовного оточення, рівня мовної підготовки студентів-першокурсників; систематично праџювати над розширенням лексичного професійного мінімуму студентів $і$ збагаченням їхнього мовлення, щзо відповідає нормам літературної мови, застосовуючи інтерактивні імітаційні методи навчання; залучати студентів до науково-дослідницької діяльності, виховної роботи; мотивувати студентів до постійного мовного самовдосконалення тощо.

Ключові слова: культура мовлення; студенти-першокурсники; професійна діяльність; нормативність мовлення; мовленнєві уміння.

Jim. 4.

Svitlana Yatsiv, Ph.D.(Pedagogy), Associate Professor of the English Philology Department Vasyl Stefanyk Precarpathian National University

\section{DEVELOPING SPEECH CULTURE OF FRESHMAN STUDENTS IN THE VIEW OF TODAY'S CHALLENGES}

Improving the culture of student's speech is an integral part of forming the professional and business skills of future specialist, the organic need of their education. A prerequisite for a highly-spoken culture of future specialists is the observance of the rules concerning oral speech: orthoepic, lexical, grammatical, stylistic. The main qualities of professional speech of students are: normativity/correctness, purity, content, appropriateness, consistency, accuracy, expressiveness. High level of speech culture of the future specialist is defined as communicative competence. For the effective culture formation of professional speech the science-based principles must be followed: structural, functional, communicative, situationality, consciousness of learning, the use of intractive and imitation methods of learning, as they give the opportunity to bring the situation of communication as close as possible to life, they promote the level of speech culture of future specialists by eliminating their speech mistakes.

The student's speech preparation requires improvements. In our opinion, the level of student's speech culture is raising if: the formation of language skills of the future specialists bases on an communicative and active aspects. The main focus at the Ukrainian language lessons is to develop oral language, taking into account the peculiarities of region, language environment, level of language training of freshman students, to work systematically on the development of students' lexical minimum and their speech enrichment that meets the standards of literary language, using interactive and imitation methods of learning, to involve students in research, to motivate them for continuous language self-improvement.

Keywords: speech culture; freshman students; professional activity; normativity; language skills.

П остановка проблеми у загальному вигляді. Формування мовленнєвої культури - одне 3 нагальних питань сьогодення. Це не лише філологічна, а й суспільно-політична, освітня проблема: вона в той чи інший спосіб пов'язана з найрізноманітнішими видами комунікації і стосується всіх носіїв української мови. Важливо зазначити, що сьогодні майже кожний третій член українського суспільства здобуває середню спеціальну або вищу освіту, утім досконалий рівень володіння культурою мовлення не став загальнонаціональним $[2,68]$. Справді, за умов розвитку державності й демократизації суспільства, розширення сфер функціонування української мови як державної особливої ваги набуває культура усного мовлення - найважливішого засобу спілкування, виховання і всебічного розвитку особистості. Відповідно до сучасних потреб ухвалено низку документів, які визначають шляхи реалізації наскрізного завдання в галузі мовної освіти, ухвалено Закон "Про забезпечення функціонування української мови як 


\section{ФОРМУВАННЯ МОВЛЕННСВОЇ КУЛЬТУРИ СТУДЕНТІВ-ПЕРШОКУРСНИКІВ}

У РАКУРСІ ВИКЛИКІВ СЬОГОДЕННЯ

державної”. Державний документ “Національна доктрина розвитку освіти України у ХХІ столітті”, окреслюючи перспективиподальшого вдосконалення навчально-виховного процесу, наголошує на тому, що “освіта сприяє формуванню високої мовної культури та мовної компетентності громадян, поваги до державної мови" [2, 4]. Водночас у практичному вимірі ситуація з мовленнєвою культурою українців доволі складна. На жаль, не є винятком і студентство. У зв'язку з цим важливе значення має робота, спрямована на формування культури українського мовлення майбутніх фахівців будь-якої галузі.

Аналіз останніх досліджень і публікацій. У науковій літературі проблемі формування культури мовлення особистості, студентства зокрема, присвячено чимало досліджень (Н. Бабич, Г. Білавич, А. Коваль, Г. Кузнецова, В. Мельничайко, О. Онуфрієнко, М. Пентилюк, С. Шевчук та ін.), однак проблему, порушену в назві статті, учені грунтовно не вивчали.

Мета статті - 3'ясувати рівень культури мовлення студентів-першокурсників, проаналізувати мовленнєві помилки, яких вони припускаються, окреслити заходи, спрямовані на формування мовленнєвої культури майбутніх фахівців.

Виклад основного матеріалу. Перед вищою школоюстоїтьзавданнялпідготувати висококваліфікованих фахівців,якідосконаловолодіютьпрофесійниммовленням, послуговуються офіційно-діловим, науковим та іншими стилями, мають чітке уявлення про терміни та доречне і правильне їх використання у професійному мовленні, уміють висловлюватися на професійну тему, уникаючи змішаних і соціальних діалектизмів, мають навички культури професійного спілкування, володіють мовленнєвою культурою тощо [1; $3 ; 4]$.

Одне із завдань дослідження полягає у з'ясуванні рівня володіння культурою мовлення студентів-першокурсників, визначення стану їхньої мовленнєвої підготовки в загальноосвітній школі. Задля цього використовували спостереження, анкетування, інтрв'ювання, виконання завдань тощо.

Було розроблено запитальник, який запропонували студентам-першокурсникам Прикарпатського національного університету мені Василя Стефаника (у дослідженні взяли участь 120 осіб). Запитання анкети мали на меті виявити: усвідомлення кожним студентом ролі досконалого мовлення в майбутній професійній діяльності; знання конкретних якостей літературного мовлення; здатність аналізувати й оцінювати власне мовлення; бачення студентами шляхів поліпшення свого мовлення.
Відповіді на перше запитання анкети “Чи вважаєте Ви українську мову основним засобом майбутньої професійної діяльності?” засвідчили, що повне усвідомлення ролі досконалого мовлення властиве тільки 28\% першокурсників, які вбачають у ньому необхідний і важливий засіб реалізації всіх функцій людської діяльності, змістом якої є не лише спілкування, передача знань, набуття певних умінь і навичок, а й формування духовно багатої, творчої особистості. Близько $47 \%$ респондентів частково усвідомлюють мову як основне знаряддя майбутньої професійної діяльності, вони загалом розуміють їі важливість у майбутній професійній діяльності, однак пов'язують цей процес здебільшого з навчанням. У $25 \%$ студентів зафіксовано поверхневе розуміння проблеми (першокурсники зазначають про важливість досконалого мовлення, але не аргументують свою відповідь (до прикладу: “мовлення - основне знаряддя вчителя" та ін.).

Досить розмаїтими у змістовому сенсі стали відповіді першокурсників на запитання “Яким повинне бути мовлення фахівця будь-якої галузі знань? Які мовленнєві якості Ви вважаєте необхідними для фахівця?" Більшість опитаних відповіла, що таке мовлення має бути: “культурним” (45 \%); “без суржику, вульгаризмів, слів-паразитів” (31 \%); “офіційним” (8\%); “інтелігентним" (6\%); “приємним" (10\%), “красивим” (8\%) тощо. Як бачимо, респонденти слушно вважають, що у професійному мовленні не повинні використовуватися мовні покручі, вульгарні слова, слова-паразити, діалектизми, воно повинне бути вільним від зайвих і суржикових слів. Водночас чіткої спрямованості на досягнення високого рівня мовленнєвої культури майбутнього фахівця в цих відповідях не простежуємо. Лише $6 \%$ респондентів змогли запропонувати повний перелік мовленнєвих якостей, які у своїй сукупності становлять культуру професійного мовлення. Окремі студенти називали декілька таких ознак: нормативність, точність, логічність, послідовність, виразність. Під нормативністю/ правильністю респонденти мали на увазі відповідність чинним правилам: “так вимовляють, наголошують”, “так треба”, “так прийнято говорити”.

До недоліків власного мовлення (запитання “Які недоліки Ви помічаєте у власному мовленні? Які мовленнєві труднощі відчуваєте під час спілкування?” майбутні фахівці віднесли невміння логічно і послідовно викладати власні думки, багатослівність, ненормативність мовлення, звуки-паразити, суржик, невиправдані повтори, до недоліків психологічного характеру - хвилювання, 
невпевненість, що зумовлені відсутністю фактичних знань і сталих мовленнєвих умінь і навичок. Одну з причин такого стану вбачаємо в недостатній мовній підготовці вчорашніх школярів, незначному лексичному запасові, недостатній практиці комунікування.

Відповіді студентів-першокурсників на запитання анкети "Які Ви вбачаєте шляхи підвищення власної мовленнєвої культури?” засвідчують, що майбутні фахівці готові підвищувати рівень культури мовлення, дбати про своє професійне зростання (92\% осіб). 3-поміж шляхів поліпшення мовленнєвої культури респонденти назвали: “спеціальні заняття 3 культури мовлення” (30 \%); “українська мова (за професійним спрямуванням)” (53 \%); “індивідуальні заняття $з$ викладачем” (7 \%); “спілкування 3 викладачами університету”(9 \%); “постійне спілкування нормативною українською мовою” (23\%); “читання художньої літератури” (10\%), самовдосконалення (6\%) тощо.

Отже, на підставі результатів анкетування, власного багаторічного досвіду праці у закладах вищої освіти, можна зробити певні проміжні висновки: студенти-першокурсники загалом усвідомлюють роль досконалого мовлення в майбутній професійній діяльності, водночас не здатні аргументувати власну думку; більшість майбутніх фахівців не мають чіткого уявлення про складники культури професійного українського мовлення, мають недостатній рівень знань про це зі шкільної програми (тільки незначна кількість опитаних студентів змогла дати визначення поняття “мовленнєва культура”), звідси виникає потреба в опануванні студентами теоретичних відомостей про культуру та якість літературного мовлення; майбутні фахівці усвідомлюють потребу у підвищенні рівня володіння мовленнєвою культурою, виокремлюють мовленнєві негаразди, які трапляються в повсякденній мовленнєвій діяльності, означують конкретні шляхи поліпшення власного мовлення.

За результатами власних спостережень на заняттях зі студентами-першокурсниками зазначимо: більшість 3 них у загальноосвітній школі оволоділа середнім рівнем мовленнєвої підготовки, юнаки та дівчата неглибоко зі шкільного курсу засвоїли мовленнєву нормативність, у першокурсників недостатньо сформовані необхідні для здійснення процесу комунікації мовленнєві уміння і відсутні стійкі навички монологічного й діалогічного мовлення. Такий рівень мовленнєвої підготовки пояснюється переважно об'єктивними причинами: більшість студентів - мешканці сільської місцевості Західної
України, де вивченню мови в загальноосвітній школі не вистачає системності і таке навчання зводиться часто до тренування навичок письма під диктовку чи підготовки тестів до складання ЗНО з української мови; на рівень мовленнєвої підготовки взагалі й культуру мовлення студентів зокрема впливає те мовне середовище, у якому вони перебували до вступу до вишу: нерідко у вихідців із сільської місцевості в мовленні переважають територіальні та змішані діалектизми, а в мешканців міста - змішані та соціальні.

Це актуалізує думку, що мовленнєва підготовка студентів потребує обов'язкового вдосконалення. Один зі шляхів цього складного процесу - комунікативно-діяльнісний підхід до вивчення курсу "Українська мова (за професійним спрямуванням”, вивчення курсу за вибором “Культура професійного мовлення", метою яких є навчити майбутніх фахівців користуватися всіма багатствами мовних засобів, у сприянні викладачів постійному збагаченню словникового запасу студентів, поглибленому засвоєнні норм літературної мови, формуванні умінь і навичок зв'язного усного й писемного професійного мовлення, урешті, формуванні риторичної культури майбутніх фахівців. На нашу думку, удосконалити мовленнєві уміння і навички студентів можна і в процесі спілкування шляхом усунення з їхнього мовлення недоліків. Таку можливість дає застосування інтерактивних імітаційних методів у навчанні української мови (за професійним спрямуванням), оскільки ділові ігри максимально наближають до життя усі можливі ситуації спілкування. Ефективно впливає на формування мовленнєвої культури студентів і їхня дослідницько-пошукова робота в наукових гуртках та проблемних групах, написання тематичних есе, участь у Всеукраїнському конкурсі студентських наукових робіт, Всеукраїнському диктанті національної єдності, конкурсі знавців української мови імені Петра Яцика та інших заходах, які влаштовують на факультетах під час святкування Дня української писемності тощо.

Дослідники пропонують низку “рецептів" підвищення мовленнєвої культури майбутніх фахівців. Слушними, до прикладу, є думки Н. Кривець: “виробити стійкі навички мовленнєвого самоконтролю і самоаналізу; не говорити квапливо - без пауз, “ковтаючи” слова; частіше “заглядати у словник”, правопис, посібники зі стилістики; вивчати мовлення майстрів слова; читати вголос, із дотриманням усіх аспектів нормативності; заучувати напам'ять художні твори, причому не тільки віршовані; 
оволодівати жанрами, видами писемного мовлення, зокрема ділового мовлення; привчити себе до систематичного запису власних думок та спостережень, щоденникових записів, сімейної хроніки тощо; виробити звичку читання з “олівцем у руках" - жоден цікавий і вартісний вираз не повинен бути втрачений для вас" $[4,15]$.

На нашу думку, рівень мовленнєвої культури студентів підвищиться, якщо: формування мовленнєвих умінь і навичок майбутніх фахівців здійснювати на комунікативно-діяльнісній основі; основну увагу на заняттях з української мови (за професійним спрямуванням) приділяти розвитку усного мовлення студентів 3 урахуванням особливостей регіону, мовного оточення, рівня мовної підготовки студентів-першокурсників; систематично працювати над розширенням лексичного професійного мінімуму студентів i збагаченням їхнього мовлення, що відповідає нормам літературної мови, застосовуючи інтерактивні імітаційні методи навчання; залучати студентів до науково-дослідницької діяльності, виховної роботи; мотивувати студентів до постійного мовного самовдосконалення тощо.

Отже, удосконалення культури мовлення студентів - невід'ємна частина формування професійних і ділових якостей майбутнього фахівця, органічна потреба національного виховання фахівців у галузі освіти. Необхідною умовою високої мовленнєвої культури майбутніх спеціалістів у є дотримання норм, що стосуються насамперед усного мовлення: орфоепічних, лексичних, граматичних та стилістичних. Найважливішими якостями професійного мовлення студентів є нормативність/правильність, чистота, змістовність, доречність, послідовність, точність, виразність. Процес мовної комунікації студентів - майбутніх фахівців - здійснюється за допомогою різних видів мовленнєвої діяльності: слухання, читання, говоріння, письма. Для сприйняття мовлення (слухання, читання) студенти повинні володіти знаннями, що допомагають пізнавати мовні форми i співвідносити їх з позамовною діяльністю. Висока мовленнєва культура майбутнього фахівця визначається насамперед комунікативною компетенцією, що передбачає наявність у мовця умінь будувати текст в усній чи писемній формі, уникаючи сленгу, діалектизмів, інших мовних покручів, послуговуючись офіційно-діловим, науковим та іншими стилями, умінь грамотного професійного висловлювання. Для ефективного формування культури професійного мовлення майбутніх спеціалістів варто дотримуватися науково обгрунтованих принципів: структурного, функціонального, комунікативної спрямованості, ситуативності, свідомості навчання, доцільно використовувати інтерактивні імітаційні методи навчання, оскільки вони дають можливість максимально наблизити до життя ситуації спілкування, сприяють підвищенню рівня мовленнєвої культури майбутніх фахівців шляхом усунення з їхнього мовлення помилок.

Подальших досліджень потребує питання розроблення методичної системи формування культури мовлення студентів у процесі навчальної та позанавчальної діяльності, створення сприятливого мовного середовища у стінах університету, яке здатне забезпечити умови для ефективної мовної підготовки майбутніх фахівців.

\section{ЛIТЕРАТУРА}

1. Білавич Г., Савчук Б. Українське наукове мовлення в контексті наукової діяльності майбутніх педагогів. Інноватика у вихованні. Збірник наукових пращь. 2017. Випуск 6. С.67-75.

2. Державна національна програма "Освіта" (Україна XXI ст.). Київ : Райдуга, 1994. 62 с.

3. Кузнецова Г. Культура наукової української мови у фаховій підготовці майбутніх освітян. Проблеми підготовки сучасного вчителя. 2012. № 6. С. 213-220.

4. Усне та писемне ділове мовлення: культура мови державного службовця: метод. рекоменд. / уклад. Н. Б. Кривець; Донецька обласна державна адміністрація. Донецьк: Донецький обласний центр перепідготовки та підвищення кваліфікації працівників органів державної влади, органів місцевого самоврядування, державних підприємств, установ і організацій, 2013. 18 с.

\section{REFERENSES}

1. Bilavych, H. \& Savchuk, B. (2017). Ukrainske naukove movlennia v konteksti naukovoi diialnosti maibutnikh pedahohiv [Ukrainian scientific speech in the context of scientific activity of future teachers]. Innovation in education. Collection of scientific works, Issue 6 , pp. 67-75. [in Ukrainian].

2. Derzhavna natsionalna prohrama "Osvita" (Ukraina XXI st.) (1994). [The State National program "Education"(Ukraine 21 century]. Kyiv, 62 p. [in Ukrainian].

3. Kuznetsova, H. (2012). Kultura naukovoi ukrainskoi movy u fakhovii pidhotovtsi maibutnikh osvitian [Culture of scientific Ukrainian language in the context of professional training of future educators]. The problems of the modern teacher's preparation, Issue 6, pp.213-220. [in Ukrainian].

4. Usne ta pysemne dilove movlennia: kultura movy derzhavnoho sluzhbovtsia: metod. rekomend (2013) [Oral and writing business speech: the culture of employee: guidelines]. Donetsk, 18 p. [in Ukrainian].

Стаття надійшла до редакції 20.09.2019 